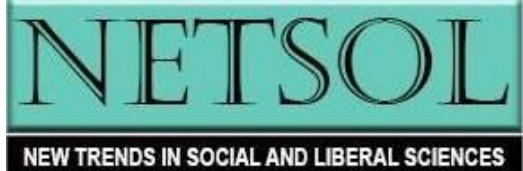

An Interdisciplinary Journal

http://www.netsoljournal.net/

Volume 4, Issue 2, pp. 24-43, Fall 2019

https://doi.org/10.24819/netsol2019.06

Date Submitted: April 30, 2019

Date Accepted: August 3, 2019

\title{
Is the World Chaos, a Machine, or Evolving Complexity? How Well Can We Understand Life and World Affairs?*
}

\author{
Walter C. Clemens, Jr., Boston University, Professor Emeritus \\ Stuart A. Kauffman, Institute for Systems Biology
}

\begin{abstract}
Chaos, machine, or evolving complexity? The butterfly effect suggests a world in chaos - with linkages so random or nuanced that just to measure or pre-state them is virtually impossible. To predict how they will interact is even less feasible. Thanks to "adjacent possibles" and the contradictory impulses of human behavior, much of our world appears to move in random spasms. Every new technology and policy outcome creates opportunities to push society in new and often unforeseen directions, driven by human agents who may introduce crucial but unpredictable goals, strategies, and actions. Against this view, complexity science seeks to identify patterns in interactive relationships. Many patterns can be plotted and, in some cases, foreseen. A comparison of political entities across the globe points to certain factors conducing to societal fitness. Analysis of states that have declined in fitness suggests why their strengths turned to weaknesses. A survey of societies that were relatively democratic points to several factors that contributed to their acquiring authoritarian regimes. Scientists and scholars can unveil some elements of order but should strive to do so without hubris. Wise policymakers will strive to channel both the "actuals" and "adjacent possibles" that then arise toward constructive futures.
\end{abstract}

Key Words: Complexity Theory, World History, Politics, Globalization, Technology

*For helpful comments on an earlier draft, the authors thank some participants in the Ninth International Conference on Complex Systems, Cambridge, MA July 2018 and two anonymous reviewers for this journal.

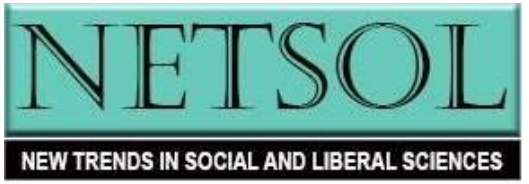


"Who could ever calculate the path of a molecule? How do we know that the creations of worlds are not determined by falling grains of sand?” Victor Hugo, Les Misérables

"To see a World in a Grain of Sand

And a Heaven in a Wild Flower,

Hold Infinity in the palm of your hand

And Eternity in an hour." William Blake, Auguries of Innocence

\section{The Vision}

"There is an hour in the night, when the whole world is silent,

And in that hour of visions and marvels,

The living chariot of the universe [mirozdaniya]

Openly rolls through the sanctuary of the heavens.

Then the night thickens, like Chaos on the waters

Oblivion, like Atlas, grips the earth

And only the Muse's virgin soul

Is, in prophetic dreams, disturbed by the gods." Fyodor Tyutchev (1803-1873)

\section{Eros and Logos}

Here is a paradox: The world manifests both chaos and order. Ancient Greeks saw a place for both principles. Primeval chaos gave birth to the god Eros, the driver of creativity and procreation. But Greeks also bowed to Logos - the ordering principle that accounted for the orderly movements of the heavens. Ancient Greeks also claimed that, below the heavens, life on earth bubbles with creative chaos - a realm where humans and gods interact, sometimes driven by the whims of fate. Another factor adding to chaos is the role played by Psyche, worshipped by Greeks as the goddess representing the human soul. She was portrayed in ancient mosaics as a goddess with butterfly wings. Psyche was ancient Greek for "butterfly," but psyche also meant "soul, spirit, breath, life or animating force." Calculations of human behavior are often derailed by the unpredictable gyrations of the human psyche. As Heraclitus put it, "The world bubbles forth." The difficulty in measuring and forecasting is summed up in the "butterfly effect." Chaos theory warns that we cannot predict the impact of a flapping butterfly wing in China on storm clouds over Texas, if only because of errors in the initial measure. A small change in one state of a deterministic nonlinear system can result in large differences in a later state.

Chaotic systems are characterized by sensitivity dependence and nonlinearity. As Robert Bishop (2017) notes, Aristotle was already aware of what we now call sensitive dependence. He observed that "the least initial deviation from the truth is multiplied later a thousand-fold." Edward Lorenz $(1963,1965)$ and others have demonstrated how small disturbances can grow explosively to produce substantial effects on a physical system's behavior.

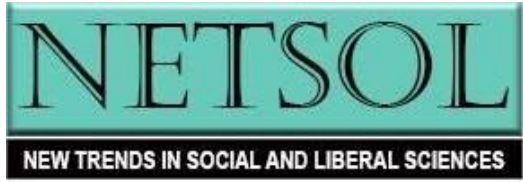


More than twenty centuries since the glory that was Greece, most scientists accept that there is a domain of logos--physics. Building on Isaac Newton, Albert Einstein, and quantum mechanics, General Relativity and quantum mechanics are verified to thirteen decimal places, and our space vehicles can navigate to Saturn. Still, even the paradigm of quantum mechanics can be questioned. Bernardo Kastrup (2018) reports that an increasing body of evidence renders the current paradigm untenable.

\section{Why Prediction Is Difficult If Not Impossible}

The human psyche and the butterfly effect, along with the twists and turns of what Machiavelli called fortuna, make prediction next to impossible in many domains. Another factor, the adjacent possible, prevents us from knowing what can happen and thus what will happen. New life forms and new tools open unimagined doors. Consider the screwdriver. Can anyone list all its possible applications? A screwdriver can not only insert a screw. It can also open a can of paint, wedge a door open, scrape putty off a window, apply heavy paint to canvas, or spear a fish. Turned into a fishing spear, it can be rented to a tourist and start a new business. The number of ways a screwdriver can be used is indefinite but not infinite. Furthermore, the different uses of a screwdriver have no ordering relation among them. Mathematically, they form merely a nominal scale. No rule-following-procedure or algorithm can list all the possible applications of a screwdriver or pre-state its next new application.

A similar problem permeates biological evolution and bacterial systems in a new environment. Imagine that some molecular screwdriver in a bacterium finds a use that enhances the fitness of that bacterium in its new environment. Given heritable variation, natural selection may well select that new use, and a new biological function will come to exist in the evolving biosphere. Still, we cannot say beforehand what that new function will be. For example, feathers designed for thermoregulation may be co-opted for flight. The adjacent possible principle is implicit in Darwin's term "exaptation." It describes a trait that has been co-opted for a use other than the original job for which it evolved. For example, the heart is designed to pump blood, but the heart makes sounds. Darwin realized that the product of an organ with no selective significance in one environment might be of use in another. If so, it could be selected for a new function--an exaptation. For example, the swim bladder housing both air and water allowed a fish to sense neutral buoyancy in the water column. The swim bladder evolved from the lungs of lung fish. Some lungs got water in them, housing air and water, and were poised to evolve into swim bladders. The swim bladder is like a new use for a screwdriver; it cannot be pre-stated and yet drives further evolution. The swim bladder opens more new possibilities for further evolution. Once the bladder exists, a worm or bacterium might evolve to live inside one.

Do we think that natural selection "acted" to craft a functioning swim bladder from the lungs of lung fish? Yes. But did selection "act" such that a worm or bacterium could evolve to live in swim bladders? No. Evolution crafts the very ways it can next evolve--guided by no entailing laws. Evolution creates the very possibilities of its future evolution without selection to achieve them. In short, evolution is sucked into the very possibilities it creates.

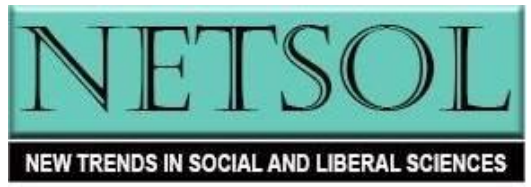


In physics, one can always pre-state the "phase space" of all possible values of the relevant variables in the process. Pre-stating the phase space is necessary to write Newton-like laws of motion for the physical system. But we cannot do this for biological evolution or politics or humanity's future. The "phase space" of evolution includes biological functions, such as the use of feathers for flight along with the unpre-statable new uses of the molecular screwdriver in the bacterium. If we cannot pre-state the phase space of biological evolution, we cannot write laws of motion for that evolution. We cannot know the relevant variables that will come to exist. Since we can write no laws of motion for the evolving biosphere, we cannot integrate those laws of motion. No laws dictate the evolution of the universe.

\section{Self-Organized Criticality}

Searching for logos, the aspiring meta-science of complexity science embraces concepts and methods from other fields-emergence, coevolution, punctuated equilibrium, and selforganized criticality. The late Per Bak suggested that the earth quakes on the same fundamental principles as a simple sand pile, in which avalanches of various sizes help keep the entire system stable — a process he called "self-organized criticality." The basic concept is illustrated by a sand pile or hour-glass in which each additional grain may trigger a small or a large avalanche. While these small instabilities paradoxically keep the sand pile stable, once the pile reaches a critical point, there is no way to tell whether the next grain to drop will cause an avalanche or how large a given avalanche will be. All one can say for sure is that smaller avalanches will occur more frequently than larger ones. The size distribution of these sand slides is a power law. The precise moment of transition - when the system is halfway between one phase and the other — is called the critical or tipping point.

In physics, self-organized criticality (SOC) is a property of dynamical systems that have a critical point as an attractor. SOC is typically observed in slowly driven non-equilibrium systems with extended degrees of freedom and a high level of nonlinearity. The idea works well to explain how slow movement of tectonic plates can generate small or large earthquakes. Bak began to see the stabilizing role of frequent smaller collapses wherever he looked. His 1996 book, How Nature Works: The Science of Self-Organized Criticality, extended the concept beyond simple sand piles to other complex systems: financial markets, traffic jams, biological evolution, the distribution of galaxies in the universe, and even the brain. Bak's hypothesis implies that most of the time, the brain teeters on the edge of a phase transition, hovering between order and disorder. Localized episodes of disordered brain activity may help keep the overall system in healthy balance (Ouellette 2014; Pezard and Nandrino 2001).

The applications of SOC go well beyond granular piles but the basic picture remains the same: many slowly driven nonequilibrium systems organize in a poised state - the critical state - where anything can happen within well-defined statistical laws. The seismic system is probably the most direct example of a self-organized critical phenomenon in nature. The relative movement

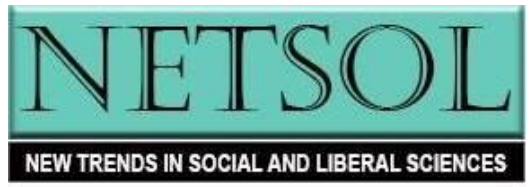


of tectonic plates causes strain to build up along the plate boundary. When the static friction cannot sustain the stain anymore, it is released through earthquakes (Pruessner 2012). ${ }^{1}$

Might the evolving biosphere be self-organized criticality? The size distribution of extinction events appears to follow a power law with many small extinction events and few large ones. Models predicting this distribution suggest that the biosphere could be "critical" (Kauffman 1995).

\section{The Adjacent Possible and the Global Economy}

The "adjacent possible" refers to what can arise next given what is actual now. Once there are IPhones, apps are in the realm of the adjacent possible. But we cannot pre-state what is in this realm. Our incapacity to see the potentials in this realm blocks our ability to forecast the global economy. Consider the Turing machine. Conceived by Alan Turing in 1936, the machine did not cause, but enabled, the invention of the mainframe computer and IBM. They, in turn, did not cause but enabled, along with the chip, the invention of the personal computer. Soon, Apple did not cause but enabled the invention of word processing; Microsoft did not cause but enabled file sharing, which did not cause but enabled the invention of the modem and then the World Wide Web, which did not cause but enabled the invention of web-based businesses such as eBay and Amazon, which put content on the web that enabled Google. Soon, cell phones abetted the Arab Spring. All this made Facebook possible, which made it possible for foreign agents to influence French, UK, and U.S. elections and alter the nature and direction of world affairs. Each innovation spawns a new Actual that makes possible another innovation. The global economy takes shape in the evolving framework of the very possibilities that it, with little or no foresight, creates. The very creativity of historical evolution expands what is next possible for the world economy.

Are there discernable patterns in economic and political development? If so, would knowledge of these patterns be useful to policy-makers and entrepreneurs? Georg Hegel, Karl Marx, Walt Rostow, and Joseph Schumpeter all had visions of a kind of dialectical movement thesis, antithesis, synthesis. Each vision contains kernels of deep insight but did not capture accurately the changing dynamics of reality. Each approach helps explain what happened in certain times and places - Marx for nineteenth century Europe and Donald Trump's America (Clemens 2018); Rostow for post-World War II United States; Schumpeter for the US economy in the 1920s (Nicholas 2003) and again in the 1950s-1960s (Auerswald 2007). ${ }^{2}$

\footnotetext{
${ }^{1}$ As Pruessner argues (2012), avalanches of various sizes can be literal--as in a granular pile or the seismic system, or they can be metaphorical like mass extinctions in biology or stock market crashes (Pruessner 2012).

${ }^{2}$ Are firms with strong market positions powerful engines of technological progress? Joseph Schumpeter thought so. His hypothesis has proved difficult to verify empirically but one sees Schumpeterian market-power and creativedestruction effects in a sample of early-twentieth-century US industrial firms. Schumpeter was correct that an efficiently functioning capital market has a positive effect on the rate of innovation. Innovation flourished: 21 percent of patents assigned between 1920 and 1928 were still cited in patents granted between 1976 and 2002. US firms with high levels of market power in the 1920s tended to be quite innovative in late years. They had strong incentives to do so preemptively because the threat of creative destruction loomed in the product market. (Nicholas 2003).
}

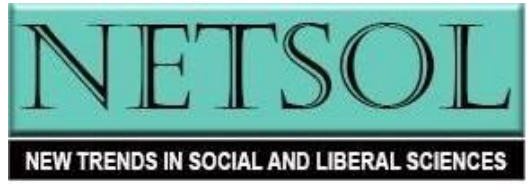


Decades before Marx, Georg Hegel understood the adjacent possible as the dialectical unfolding of history. Converting Hegel's idealist dialectic to materialism, Karl Marx also described the workings of the adjacent possible. Capitalism developed industry and social relations so that they prepared the way for the next stage of development — socialism. Though appealing in theory, state socialism has failed in practice. The great Soviet experiment with publicly owned means of production slowed and then collapsed. The Soviet economy's rapid growth in the 1930s appeared to result from the regime's ability to harness economies of scale but derived even more from its mobilization of surplus labor (Auerswald 2007). Beijing's leaders today still praise socialism, but China's growing economic power results more from its Leninist (state directed) capitalism - cheap labor paired with vast capital - than from its state-owned industries. However, state-owned and planned economies fail because they try to pre-state what goods and services are needed and then create plans to produce them. Such plans fail because economies grow into their adjacent possibles in which new, unforeseeable goods and production capacities arise, as in the way that the Turing machine generated the World Wide Web.

Trying to devise a non-Communist manifesto, Walt Rostow predicted that the stages of economic growth would lead from traditional subsistence to "take-off" to an age of mass consumption and beyond. His liberal capitalist model was based mainly on the US example, but his rosy forecast has been falsified by America's growing inequality (Rostow 1960). The Austrianborn, Harvard economist Joseph A. Schumpeter forecast gales of creation and destruction leading to new waves of creation. Indeed, entire industries and jobs were replaced by innovations such as the automobile. But the creative destruction thesis conveys just part of a more complex evolution. Could Schumpeter's insights mean that the global economy is also self-organized critical? Small and large avalanches of "Schumpeterian gales of creative extinction" have taken place in the United States and elsewhere. Such a "gale" occurs when some new product drives out an older good - as when autos replaced horses for transport. Many erstwhile goods - the saddlery, watering troughs, horse shoes, the smithy — nearly disappeared as new businesses came in - the oil industry, paved roads, motels, and suburban housing for people who now needed cars. ${ }^{3}$

Is there a power law distribution of gales of creative destruction fitting real economic data? A study at the Harvard Center for International Development (Klemic et al. 2012) found that world trade network datasets showed that the dynamics of innovation in the world economy follows a pattern of creative destruction. Products systematically tend to co-appear in national economies in bursts of creative cascades followed by massive disappearances of existing products in subsequent years. Also, there is a tendency for more complex products to drive out less complex ones. The

\footnotetext{
${ }^{3}$ Not so long ago the largest industries in the U.S. were in the auto industry. Among the ten largest employers in 1955 were GM, Chrysler, US Steel, Standard Oil of New Jersey, Amoco, Goodyear, and Firestone. In 2014 four of the ten largest companies by total employees were Walmart, Target, Sears, and Kroger. Two companies on the list from 2014 were IBM and Hewlett Packard - on the tip of an iceberg comprising dozens of large tech companies with high margins, rapidly growing sales, and well-paid work forces. This group included Dell, Google, Cisco, and Oracle. With almost no exceptions, these high-tech firms did not exist five decades earlier (Perry 2014).
}

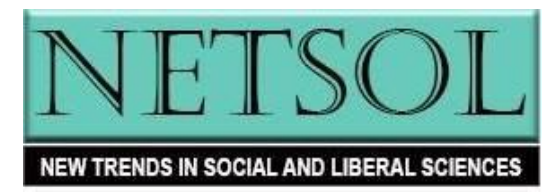


growth trajectory of a country's product output diversity can be understood by an evolutionary model of Schumpeterian economic dynamics.

An earlier study (Hanel et al. 2007) also found evidence of a power law of distribution in gales of creative destruction in economic as well as biological systems. Looking at the end phase, researchers found that a massive loss of diversity can be triggered by very small external fluctuations. The team proposed a dynamical model of diversity that captures spontaneous creation and destruction processes. The emergent time series showed rich diversity dynamics, including power laws as observed in actual economic data such as firm bankruptcy data. The researchers believed that their model presented a way to test the creative destruction hypothesis.

Besides the appearances and disappearances of products, however, the life-enhancing quality of innovations must also be considered. Economic historian Robert Gordon (2017) argues that the great inventions and innovations - electricity, modern plumbing, the internal combustion engine - took place in the late nineteenth century and accounted for a century of unprecedented growth, 1870-1970. More recent computer-based innovations contributed to a modest upswing in US economic growth at the turn of the twentieth century (1994-2004). But Gordon forecast that inequality, poor education, aging, and the breakup of family life will probably impede US growth in the twenty-first century. ${ }^{4}$

Upshot: the idea of critical Schumpeterian gale may apply in recent periods of economic history but may be too simplistic to universalize. Further research may reveal a statistical law showing how economic systems evolve with small and large bursts into the adjacent possibles they themselves create.

\section{Patterns in the Maelstroms of Politics?}

If human history is critical, we should be able to map the size and distribution of events, along with the avalanches that precede or follow each event. Given the power of adjacent possibles, we can hope only to sketch alternative futures for the unfolding of human development. The collapse of the Soviet Union was a vast event that inspired a welter of alternative scenarios from the "end of history" to a resurgence of autocracy. The Trump era could initiate huge changes in world affairs or become only a bump on a rocky slope where the nature of subsequent avalanches is unpredictable.

One hopeful social scientist wrote: Self-organized criticality can occur in human relations if the sensitivity of individuals or groups to each other's actions increases with the passage of time, leading to cascades of sudden changes. "In this way scandals, betrayals, miscalculations and other seemingly insignificant actions can sometimes cause cabinet dissolutions, strikes, riots, electoral

${ }^{4}$ Perry (2014) cites an article in Forbes (November 19, 2011) reporting that, fifty years earlier, the life expectancy of a firm in the Fortune 500 was around 75 years, while in 2011 it was less than 15 years and declining all the time. Commenting on the Perry's posting in the same blog, Steven Hales wrote (August 18, 2014) that the new firms did not do something better but instead created entirely new markets. Supply sometimes creates its own demand. Henry Ford quipped that if he had listened to his customers, he would have built a better horse. And Steve Jobs said that the customer has no idea what she wants until she sees it.

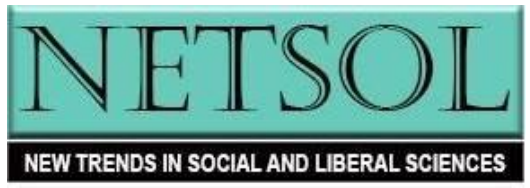


landslides, wars and a multitude of other phenomena that, until now, have seemed to have had nothing in common" (Brunk 2001). However, a skeptic might see here an unnecessary Procrustean bed. To understand phenomena such as scandals and wars does not require SOC, but our minds should remain open. History, child of Eros, may prove to be critical.

One premise of complexity studies is that common principles underpin diverse interactions - from immune systems and brains to climates and stock markets. By discovering these principles, we can learn how to build much more potent, predictive models of complex systems. Complex social systems are especially hard to model, because humans are hard to model. Humans are the atoms, in a sense, of social systems, and yet unlike atoms, each individual human is unique, a product of his or her physiology and life history. And whereas atoms are indifferent to what scientists say about them, we humans may alter our behavior when we learn what scientists are saying about us. Scientists' models of societies can change societies in ways that the models cannot anticipate. Social science may be chasing a rapidly moving target and to which it can never catch up (Horgan 2012 and 1996).

Against many signs of unpredictable behavior, complexity science hopes and seeks to identify patterns in complex relationships and then to explain if not predict their future development (Kauffman 1993; Clemens 2013; Kowalski 2015). One concern of complexity science is fitness - defined as the ability to deal effectively with complex challenges and opportunities. Students of complexity ask how societies gain and lose fitness. Let us review seven possible answers by Karl Marx, Arnold Toynbee, Jared Diamond, Acemoglu-Robinson, Ian Morris, Samuel P. Huntington, Levitsky-Ziblatt, Timothy Snyder, and Walter Clemens.

\section{Dialectical Materialism}

Karl Marx and his collaborator Friedrich Engels saw all history as class struggle pivoting on the means of production and who controls them. Marx depicted a dialectical process in which thesis generates its antithesis from which emerges a synthesis. This process pushed humanity to pass from the primitive communism of tribes to slave-holding to feudalism to capitalism. When capitalism loses its productive force and spawns an increasingly impoverished proletariat, the social system will explode into socialism and then graduate to communism. ${ }^{5}$ But the collapse of Soviet socialism in 1991 and the recent emergence in China of Leninist capitalism falsified the expectations of dialectical materialism.

\footnotetext{
${ }^{5}$ Socialism was supposed to reward people by the quality and quantity of their work. Under communism, however, Marx expected the principle to be: "From each according to his abilities, to each according to his needs." Lenin later explained that Europe's capitalists delayed a socialist revolution by imperialistic expansion into less developed countries, exploiting them to benefit Europe's ruling class who then used some of the bounty to buy off labor leaders. Stalin later claimed that the USSR had achieved socialism in 1936. Challenged by Mao Zedong's Great Leap Forward, Soviet leader N. S. Khrushchev in the late 1950s claimed that the USSR was "rapidly building the foundations of communism."
}

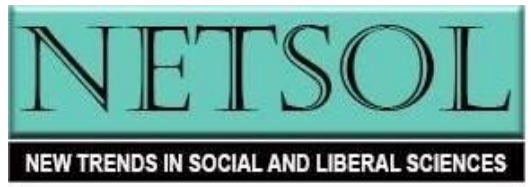




\section{Challenge and Response}

Historian Arnold J. Toynbee depicted the rise and fall of civilizations as driven by ideational as well as material factors. Having studied twenty-one civilizations, Toynbee concluded that each civilization arose as a creative response to serious challenges (such as desiccation in ancient Egypt). Over time, however, civilizations vitiate their strengths - often in war. Toynbee wrote that most civilizations rose and fell in a sequence of three-and-one-half beats: challengerally, rout-rally, rout-rally, rout. As moral and other resources became depleted, most civilizations did not respond effectively to the fourth challenge (Toynbee 1947, 49).

Both Marx and Toynbee seem to describe a "self-organized" response to complexity, with small and large avalanches of change and new opportunities in the unfolding of history. But their grand schemes faltered for many reasons, beginning with issues of definition and selection. Similar problems beset the "clash of civilization" thesis of Samuel P. Huntington (1996) and the "Thucydides trap" of Graham Allison (2017). What is a civilization? When do civilizations begin and end? Why do some civilizations and empires last less than a century while others stretch over half a millennium? What do these units include and exclude? For example, does "Islamic" civilization include Sunni, Shi'a, and all the other movements claiming to be inspired by the Prophet? Did Islamic civilization end in the eleventh, the seventeenth, or some later century? Does it continue today? What is a rout and a rally? Did European civilization suffer two routs (World Wars I and II) or one prolonged rout? What is cause and effect? Did Roman civilization die with the Peloponnesian Wars, as Toynbee suggested, or when the Huns entered Rome? Did the Great War begin when Germany challenged Great Britain, as Allison suggests, or when Kaiser Wilhelm gave Vienna a blank check to deal with Serbia (Clemens 2017)? Did the Cold War end with Mikhail Gorbachev? Did it resume with Vladimir Putin and George W. Bush?

\section{The Costs of Extractive Politics}

Daron Acemoglu and James A. Robinson (2012) also scan a long skein of history but focus on a smaller unit than civilization. Their book is entitled Why Nations Fail: The Origins of Power, Prosperity, and Poverty. They ask: What do the Neolithic revolution, the Mayan city-state, King Shyam in the Congo, and Stalin have in common? Why is South Korea many times richer than North Korea? Why is Nogales, Arizona more prosperous than Nogales, Mexico? Regimes that extract resources and taxes to benefit their elites do not endure. Systems that perpetuate or worsen inequality spawn negative feedback loops. Inclusive political institutions perform better than those designed for top-down exploitation. If these observations are valid, China's recent economic growth cannot last and Trumpian economics and politics will hit a dead end.

\section{Killer Apps}

Niall Ferguson (2011) also asks: What set the West apart from the rest of the world? Starting five centuries ago, six functional complexes or "killer apps" boosted the ascent of the West: competition, science, the property-owning democracy, modern medicine, the consumer society, and the Protestant work ethic. These six "apps" allowed the West to move ahead of the

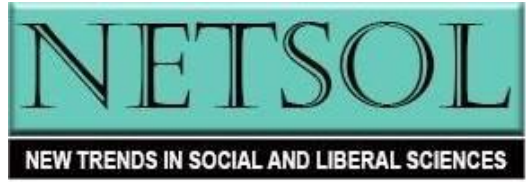


rest by opening global trade routes, exploiting new scientific knowledge, evolving representative government, increasing life expectancy, unleashing the industrial revolution, and hugely increasing human productivity. They permitted a dozen Western empires to control three-fifths of mankind and four-fifths of the world economy. As other societies embrace and absorb these same skills, Ferguson says, the West's dominance may well wither.

\section{Democracy Strangled}

How do democracies die? This is not an ivory tower speculation. In the early twenty-first century democratic values such as free and fair elections and the rule of law are under attack and in retreat globally. Samuel P. Huntington (1991) identified three great waves of democratization: from the early nineteenth century to 1922; from 1945 to 1962; from 1974 to 1991 and possibly beyond. The first two waves were followed by backsliding toward autocratic rule in many countries. Writing just as the Soviet empire disappeared, Huntington warned that another reversal was possible. His caution proved to be well founded. After the Soviet collapse in 1991, it appeared that totalitarianism had at last been vanquished and that liberal democracy would prevail. According to Freedom House (2018), however, from 2006 through 2017, democracy in 113 countries suffered setbacks as against 62 that registered gains. Freedom House in 2018 reported that $39 \%$ of the world's population was "free"; 24 percent "partly free"; and 37 percent, "not free." States that a decade earlier looked like promising success stories, such as Turkey and Hungary, were sliding into authoritarian rule. The military in Myanmar, which permitted a democratic opening in 2010, soon began a textbook campaign of ethnic cleansing. The West's democracies in the second decade of a new millennium were mired in partisan disputes over social and economic disparities, terrorism, and immigration.

The challenges within democratic states fueled the rise of populist leaders, who give short shrift to civil and political liberties. Emboldened autocrats undermined beleaguered democracies. In 2017 right-wing populists gained votes and parliamentary seats in France, The Netherlands, Germany, and Austria. Centrist newcomer Emmanuel Macron handily won the French presidency but soon met resistance from many quarters. In Germany and The Netherlands, mainstream parties struggled to create stable governing coalitions. The Trump administration scuttled US leadership in the global struggle for human freedom. Trump's "America First" policies sabotaged traditions of collective security and mutually beneficial trade (Rose 2019). His administration derided international agreements on the environment, arms control, and human rights (Frum 2018).

How do democracies die? Granted that each political culture is different, Steven Levitsky and Daniel Ziblatt (2018) sought to explain transitions from democratic to authoritarian rule — as when the Weimar Republic gave way to Hitler's dictatorship. Analysis of such cases revealed four traits of the upstart cliques that seized power: first, a weak commitment to the democratic rules of political competition; second, denial of the legitimacy of opponents; third, toleration or encouragement of violence; fourth, a readiness to curtail the civil liberties of opponents, including the media. These four factors helped Mussolini and Hitler consolidate their dictatorships in the 1920s and 1930s. A similar process ensued in South America in the 1960s and 1970s - even in

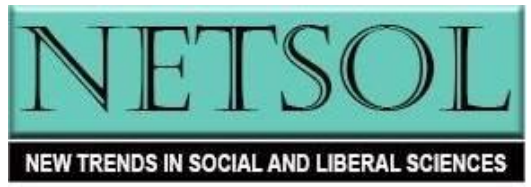


traditionally democratic Chile. In each case most citizens abdicated and permitted a dedicated minority to bypass and subvert democratic institutions and norms. Did no one object? Some citizens hoped the new, authoritarian regime could be tamed; some deemed it preferable to the apparent alternatives (for Germany in 1933, either anarchy or Communist rule)

Both in his 2016 campaign and in the first year of his presidency, Donald S. Trump's behavior fits each of the four criteria. ${ }^{6}$ In 2016 most leading Republicans regarded Trump as unworthy of the presidency. Once he was nominated and won a majority in the electoral college, however, most Republicans jumped onto his bandwagon. Despite their many claims to deep religious convictions, few Republicans opposed the bandwagon. Most abdicated. None embraced principle as did Martin Luther in 1517 when he declared: "Here I stand!"

\section{Inevitability versus Eternity}

Yale historian Timothy Snyder (2018) offers another perspective on the apparent threats to democracy in his book The Road to Unfreedom: Russia, Europe, America. The regime of Vladimir Putin, according to Snyder, presents itself as a victory for the "eternity" Weltanschauung of world affairs. History is said to circle back on itself instead of progressing toward some new but glorious future. "Eternity" means that nothing really changes. Orthodox Christian Russia was said to have traditionally been pure and, after some exceptional times, to have regained its innocence. The Kremlin said that the many non-Russians living in Russia or in its near-abroad periphery would find their true identity by bowing to the church leadership in Moscow. ${ }^{7}$ Most Ukrainians and some others, however, preferred to do their own thing in religion as well as in politics.

Like Francis Fukuyama's "end of history" theory, "inevitability" supposes that there is no ideology for humanity other than liberal democracy. Putin and his agents strive to undermine the confident worldview of Europeans and Americans, who accept the progress of Western democracy and capitalist/welfare state economics as inevitable. To this end the Kremlin used cyberwarfare to

\footnotetext{
${ }^{6}$ Thus, on February 5, 2018 Trump tweeted an attack on the leading Democrat on the House Intelligence Committee: "Little Adam Schiff, who is desperate to run for higher office, is one of the biggest liars and leakers in Washington, right up there with Comey, Warner, Brennan and Clapper! Adam leaves closed committee hearings to illegally leak confidential information. Must be stopped!" One father tweeted back: "My son has dwarfism he's 3'11", he's 13 yrs old. I try and teach him that everyone is unique. But when the president bullies people that are not as tall, what am I supposed to tell him. He's never been bullied by other children, you are the only person that's a true sick bully. Sad."

${ }^{7}$ The eternity theory emerged from the writings of Ivan Ilyin (or Il'in) (1883-1954), an arch conservative publicistphilosopher opposed to the Bolshevik revolution. His theories were prefigured in tsarist times by Nikolai Danilevskii, Rossiia i Evropa [Russia and Europe] (1871) and other Pan-Slavist writers, such as the poet-diplomat-propagandist Fyodor Tiutchev. Ilyin's lectures and books, though produced in Europe, portrayed his native Russian homeland as a pure and innocent victim of Western oppression and manipulation. Despite Ilyin's opposition to Soviet Communism, Vladimir Putin and his PR agents resurrected Ilyin's writings and even his corpse, originally buried in Switzerland, and had it reburied in Moscow in 2005. Though Ilyin inherited the "Moscow as Third Rome" tradition dating from $1523 / 1524$, the Putin regime has not yet gone so far as to portray his Kremlin as the descendant of Rome and Byzantium.
}

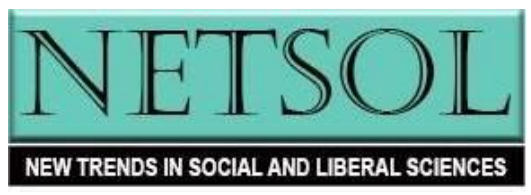


bolster the UK "Brexit" from the European Union and to foster right-wing parties in France, Germany, and elsewhere. Russian bots and trolls exploited the dissatisfactions born of growing inequality in the United States. For Trump's supporters and many Europeans, "eternity" promised a return to the era when whites and their versions of Christianity ruled without challenge. Overall, Snyder's thesis underscores the ideological divide between East and West, but it seems anchored to a particular time and place and has little relevance to most developing countries.

\section{Materialistic versus Ideational Factors}

Jared M. Diamond (1997) argued that geography explains how Europe and North America became richer and more powerful than most of Africa, Asia, and Latin America. Diamond responded to a question posed to him in New Guinea: "Why is it that you white people developed so much cargo and brought it to New Guinea, but we black people had little cargo of our own?" Diamond's answer: People in the Northern hemisphere had material assets, such as horses and cattle lacking in most of the South. Environmental advantages were amplified by positive feedback loops. Northerners mastered steel and then guns and acquired immunity to diseases they later brought to the South. Also, humans in the North, along with their ideas and innovations, could travel on an east-west axis. The achievements of Incas, by contrast, were blocked from moving east by the Andes. Diamond does not explain, however, why the achievements of Aztecs did not spread north. Nor does he explain why, despite potential east-west exchanges, it took more than a millennium for China and Europe to profit from each other's innovations.

Like Diamond, Ian Morris (2010) underscores the role of geography and other material factors. Why has the West dominated the world for several centuries? How long will this last? Morris points to four "traits" that explain the West's dominance. First is energy capture - the ability to extract energy from plants, animals, wind, and carbon to make people strong and to make things move. Second is urbanism. Despite their dysfunctions, cities require and foster effective organization, which often drives innovation. Third is information processing — the ability to obtain, store, and communicate knowledge. Fourth is the capacity to make war. Each trait is both cause and effect.

Geography certainly helps account for the privileged existence of the United States in recent centuries - near self-sufficiency in natural resources plus splendid isolation protected by great bodies of water. But South America is equally endowed and protected by oceans. The difference is partly explained by the cultural values of the Europeans, who landed and then occupied South, Central, and North America after subduing and nearly exterminating Native Americans. Those who settled in and developed the North believed in scientific knowledge and hard work; those in the South focused on exploiting the New World's mineral and other resources, the hard work done by slaves.

\section{Three Revolutions that Shape Our World}

Material factors are important but do not explain everything about human societies. Humans do not live "by bread alone." Studies of the former Soviet (Russian) and Yugoslav

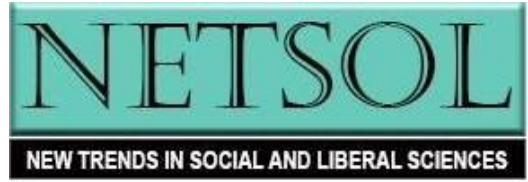


(Serbian) empires (Clemens 1991, Clemens 2013) raised the question: Why did some former Soviet republics and satellites transition smoothly and rapidly to economic and political freedom while most of them remained mired in top-down autocracies? Clemens argued that the enhancement of human potential in countries with Western Christian heritage benefited from three transformations that began five or six centuries earlier; revolutionary demands for mass literacy, freedom of thought and expression, along with respect for individual dignity — sometimes for both genders.

These revolutionary demands - triggered by John Wyclif, Jan Hus, Martin Luther, and John Comenius - benefited from and contributed to advances in publishing, science, technology, and the humanities. Each revolution proceeded in fits and starts. Over time, however, the synergies of all three revolutions helped Western societies become the highest ranked countries on the UN Human Development Index (HDI). While the index aggregates measures of income, health, and education, its rankings generally parallel the political and social rankings by Freedom House and Transparency International, as well as those of the Social Progress Index, the Global Innovation Index, and the Bertelsmann Transformation Index. Indeed, the highest ranked country on the HDI, Norway, also leads in measures of happiness (UN Development Programme, annual).

Taking the UN Human Development Index (HDI) as key indicator of societal fitness, Clemens $(2013,117)$ found that, for Christian countries, their rankings could be predicted by the date when their societies received the Bible published in the vernacular. Most Protestant countries received the Bible in the vernacular within a century after Gutenberg's first Bible in 1454-1455 (in Latin), followed soon by vernacular Bibles in Catholic regions of Germany as well as in France, Italy, and Poland, and in Jewish communities in Italy. Most Eastern Orthodox Christian countries did not have a Bible published in the vernacular until the nineteenth or twentieth century. Political and church leaders in Orthodox countries did not encourage mass literacy, free thought, and respect for individual dignity as in the lands of Western Christianity.

Sacred texts of other faiths in the vernaculars of non-Christian countries did not appear until the nineteenth or twentieth century. Nor did their publication inspire campaigns for mass literacy or free thought. Not until the late nineteenth or twentieth century did authorities in countries with Muslim, Hindu, or Buddhist traditions commit to mass education. Most continue in the twenty-first century to limit free thought. Muslims as in Indonesia, Pakistan, and Central Asia could memorize and recite but few could read Allah's word in the only authentic version classical Arabic.

Beginning with Norway, most of the top thirty places on the Human Development Index have been occupied by countries with Protestant or Catholic traditions - in recent years joined by other countries heavily influenced by Western culture and models. In 2018 Hong Kong placed $7^{\text {th; }}$ Singapore, $9^{\text {th }}$ Japan, $19^{\text {th }}$; while Israel and South Korea tied at $22^{\text {nd }}$. Of formerly Communist-led countries, Slovenia, Czechia, and Estonia, each with Western Christian traditions, placed $25^{\text {th }}, 27^{\text {th }}$, and $30^{\text {th }}$. In 2018 the two highest placed Orthodox countries - never ruled by Communists were Greece and Cyprus, $31^{\text {st }}$ and $32^{\text {nd }}$. The highest placed Muslim heritage countries were all

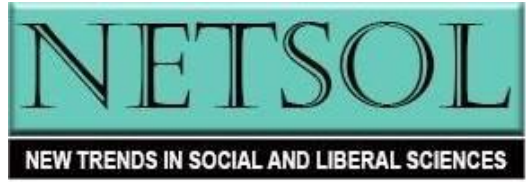


high-income oil producers - the United Arab Emirates (UAE), $34^{\text {th }}$, Brunei Darussalam and Saudi Arabia, tied at $39^{\text {th }}$.

Most states ruled by Communists now or in recent decades ranked low on the HDI. Of former Soviet republics, Protestant heritage Estonia and Catholic heritage Lithuania placed $30^{\text {th }}$ and $35^{\text {th }}$. Russia and Belarus - Orthodox but ruled by Communists for over seven decades placed $49^{\text {th }}$ and $53^{\text {rd }}$. They enjoyed nearly universal literacy under Communist rule but not the second and third revolutions - free thought and respect for individual dignity. The highest placed Muslim-tradition former Soviet republics were Kazakhstan, $56^{\text {th }}$, and Azerbaijan, $80^{\text {th }}$. China, nominally Communist and ruled by atheists, placed $86^{\text {th }}$ (up from $90^{\text {th }}$ in 2017). The three highest placed Muslim heritage countries (such as the UAE) were never ruled by Communists. Oil wealth could be a blessing or a curse - as suggested by the diverse rankings of Norway, Brunei, Qatar, Russia, Kazakhstan, and Azerbaijan. Their oil wealth raised income but did not guarantee improved health or education without enlightened liberal policies.

\section{What Does It All Mean?}

The problem of "pre-statability" calls into question whether science can ever accurately and precisely predict the future development of biological features in organisms. The development of life on earth is not entirely predictable, because no theory could ever fully account for the possibilities of evolution. The same goes for humanity - and how humans and their policies shape the biosphere. The adjacent possible concept offers a new explanation for the living world. Evernew actuals do not cause but enable ever-new, often non-statable, adjacent possible opportunities into which we are pulled. Everything may be emergent and ultimately lawless (Kauffman 2016). Logos — the power of reason — must recognize its limitations.

Our incapacity to pre-state the phase space of history precludes writing laws of motion for history. No denizens of the Roman Empire in 100 BCE knew that Christ would be born, that Saint Augustine would frame the early Church, or that Constantine would embrace Christianity with the eventual emergence of that religion as the official faith of the empire. Despite the broad horizons of Toynbee, Marx, and others reviewed here, there are no laws of history that describe and predict its detailed unfolding in some deterministic fashion. What we do see is a great variety of alternative futures based on many causes and effects, which then open new adjacent possibles. In this way, history becomes - beyond law - a vast evolving web. Human history, like all of evolution, cannot be predicted but yields the very possibilities into which it becomes. What was once possible thus becomes another historical Actual.

Curious humans want to know what lessons they can learn from history. When applied to human affairs, however, chaos theory supports historians who say that history is just one damned thing after another - as Macbeth put it, "a tale told by an idiot, full of sound and fury, signifying nothing." Even if Macbeth was wrong and life has direction and meaning, skeptics say that grand purposes cannot be grasped by mere humans. As Goethe's Faust told an aspiring student, what historians think they see in some bygone era is just a mirror of their own minds and hopes (Faust Part I, lines 575-585).

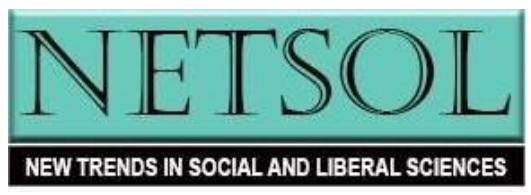


Herr Dr. Professor Faust also warns the aspiring theorist that scholarly theories may be neat and orderly but still miss the real spirit of things. "All theory is gray, but life's golden tree is green (Faust I, 2038-2039)." Indeed, "the web of thought is like a weaver's masterpiece. One step on the shuttle and a thousand threads arise... The threads flow on, unseen and subtle, each blow effecting a thousand ties (Faust I, 1922-1927)." For his student Wagner, Faust deprecated learning. Still, the aged academic conceded that a person who hopes to rise above error and falsehood could be happy. Nonetheless, he thought, "What one does not know - that is exactly what one needs, while what one does know is useless (Faust I, 1064-1067)." Much of life appears chaotic extremely difficult if not impossible to understand. Life on earth emerges in an unknowable way. Humans need an ever-clearer understanding of how wisely to garden the adjacent possible into which we rush, but cannot pre-state, with new forms of governance. Without guidance from some heavenly authority, we must grow ourselves (Kauffman 2016, 271).

Complexity theories, such as emergence and punctuated equilibrium point to patterns in the ebb and flow of life. The social science theories summarized here do help explain variations in societal fitness. Each illumines facets of the whole - like parts of the proverbial "elephant." Still, none describes or explains all that needs to be explained. None suffices to predict what will happen in politics, economics, or related fields. Some prescribe in general terms policies that could promote greater fitness - urbanization and better communications (Morris); modern medicine and Protestant work ethic (Ferguson), mass literacy plus free thought (Clemens). None of the theories can anticipate what agents - what individuals or cliques or parties — will take the stage and push life in uncharted directions. None could anticipate that a veteran Hollywood personality, a recovered alcoholic playboy, or a narcissistic real estate developer could be elected president of the United States. Nor could they predict that a Catholic Harvard grad with a Boston accent, a Georgian peanut farmer, or a black community organizer could become the US president.

Historians and social scientists have identified key variables in the rise and fall of civilizations and nations. But they probably can never anticipate the effects of individuals, such as Luther or Hitler or Donald Trump - agents who can temper or add to the adjacent possibles of existence. Of course, they are not like free radicals. They can do their thing only within the context of their environment and its openness to change. Even leaders and social activists who strive to do good may spawn negative consequences. As the Lord said to Mephistopheles: "So long as humans strive, they will make mistakes — Es irrt der Mensch, solang er strebt (Faust I, 317)."

Some aspects of reality appear chaotic — random and unpredictable. As we learn more, however, some facets of life that seemed without rhyme or reason now appear to behave in patterns that can be identified and sometimes anticipated. One of the founders of complexity science, the physicist and all-round intellectual Murray Gell-Mann, discerned the patterns and symmetries connecting the many new subatomic particles, such as protons, neutrons, and mesons being found in cosmic rays and particle accelerator blasts. He found that they clustered in groups of eight and ten, but then discovered that they could be divided into triplets of even smaller components, which

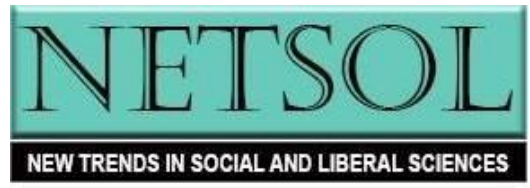


he called quarks. He later compared the simple structure of a mathematical formula to the rules of a sonnet (Gell-Mann 1994; Johnson 2019).

The idiosyncrasies of individual humans and adjacent possibles in all realms probably ensure that elements of our worlds will always be - or appear — chaotic. The world is not a machine (Kauffman 2019, 1). Still, not just biologists and physicists but also social scientists can strive to learn more about whatever patterns that lie within complexity. Some implications for policymakers may emerge - what to pursue and what to avoid in order to cultivate greater fitness for humans and all of life. Despite its failures to predict the rise of authoritarianism and antiscientism in the United States and elsewhere, the "three revolutions" thesis provides useful implications for policymakers seeking to enhance human development. They should see literacy and free thought as major priorities (far more important than ensuring big profits for munitions makers or big pharma), to be pursued in ways that nurture the dignity and well-being of every individual and ethnic/cultural grouping. Meanwhile, as scientists and scholars work to unveil elements of order, they should also strive to avoid the pitfalls of hubris.

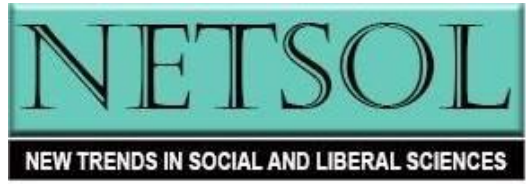




\section{References}

Acemoglu, Daron and James A. Robinson. 2012. Why Nations Fail: The Origins of Power, Prosperity and Poverty. New York: Crown.

Allison, Graham T. 2017. Destined for War: Can America and China Escape Thucydides's Trap? Boston: Houghton-Mifflin.

Auerswald, Philip A. 2007. "Retroview: Schumpeter's Century." American Interest 3, 2 (November) at https://www.the-american-interest.com/2007/11/01/retroviewschumpeters-century/ (accessed 4/20/2018).

Bak, Per. 1996. How Nature Works: The Science of Self-Organized Complexity. New York: Copernicus, Springer-Verlag.

Benen, Steve. 2015. "Poll shows Republicans rejecting evolution." September 25, 2015 at http://www.msnbc/rachel-maddow-show/poll-shows-republicans-rejecting-evolution (accessed 2/1/2018).

Bishop, Robert. 2017. "Chaos.” The Stanford Encyclopedia of Philosophy, ed. Edward N. Zalta, at https://plato.stanford.edu/archives/spr2017/entries/chaos/ (accessed 5/13/2018).

Brunk, Gregory G. 2001. "Self-Organized Criticality: A New Theory of Political Behavior and Some of Its Implications." British Journal of Political Science 31, 2 (April):427-445.

Clemens, Walter C., Jr. 2017. "Is There a Thucydides Trap? If So, How Avoid It?" Asian Perspective 41, 4 (Oct.-Dec.):717-736.

2017):519-526.

2017. "Empires Old and New." Asian Perspective 41, 3 (July-Sept. 2013. Complexity Science and World Affairs. Albany: State University of New York Press.

. 2004. Dynamics of International Relations: Conflict and Mutual Gain in an Era of Global Interdependence. $2^{\text {nd }}$ ed. Lanham MD: Rowman \& Littlefield.

Danilevski, N. IA. 1871. Rossiia i Evropa. Sanktpeterburg: Obshchestvennaia pol'za.

Diamond, Jared M. 1997. Guns, Germs, and Steel: The Fates of Human Societies. New York: W. W. Norton.

Ferguson, Niall. 2011. Civilization: The West and the Rest. New York: Penguin.

Freedom House. 2018. "Freedom in the World 2018." at https://freedomhouse.org/report/freedomworld/freedom-world-2018 (accessed 5/13/2018).

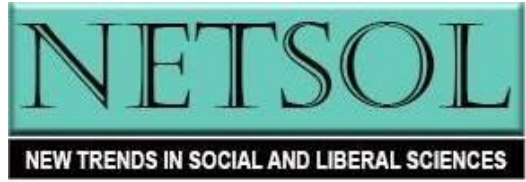


Frum, David. 2018. Trumpocracy: The Corruption of the American Republic. New York: HarperCollins.

Fukuyama, Francis 1992. The End of History and the Last Man. New York: Free Press.

Gell-Mann, Murray. 1994. The Quark and the Jaguar: Adventures in the Simple and the Complex. New York: Henry Holt.

Germain, Tiffany. 2015. "Here Are the 56 Percent of Congressional Republicans Who Deny Climate Change." February 3 at http://billmoyers.com/2015/02/03/congress-climatedeniers/ (accessed 2/6/2018).

Gleick, James. 1987. Chaos: Making a New Science. New York: Viking.

Goethe, Johann Wolfgang von. 1808-1832. Faust. Two Parts.

Gordon, Roger K. 2017. The Rise and Fall of American Growth: The U.S. Standard of Living Since the Civil War. Princeton University Press, 2017 [updated from 2016].

Hanel, R., S. A. Kauffman, and S. Thurner. 2007. "Towards a Physics of Evolution: Critical Diversity Dynamics at the Edges of Collapse and Bursts of Diversification." Phys Rev E 76, 036110 at https://www.ncbi.nlm.nih.gov/pubmed/17930309 (accessed 4/24/2018).

Horgan, John. 2012. "Can Engineers and Scientists Ever Master Complexity?" Scientific American (December 10) at https://blogs.scientificamerican.com/cross-check/canengineers-and-scientists-ever-master-complexity/ (accessed 4/24/2018).

. 1996. The End of Science: Facing the Limits of Knowledge in the Twilight of the Scientific Age. Reading, MA: Addison-Wesley.

Huntington, Samuel P. 1991. The Third Wave: Democratization in the Late Twentieth Century. Norman: University of Oklahoma Press.

1996. The Clash of Civilizations and the Remaking of World Order. New York: Simon \& Schuster.

Johnson, George. 2019. "Murray Gell-Mann, Who Peered at Particles and Saw the Universe, Dies at 89," New York Times, May 25.

Kastrup, Bernardo. 2018. "Should Quantum Anomalies Make Us Rethink Reality?" Scientific American (April 19) at https://blogs.scientificamerican.com/observations/shouldquantum-anomalies-make-us-rethink-reality/ (accessed 7/6/2018).

Kauffman, Stuart A. 1993. The Origins of Order: Self-Organization and Selection in Evolution. New York: Oxford University Press. 2000. Investigations. New York: Oxford University Press.

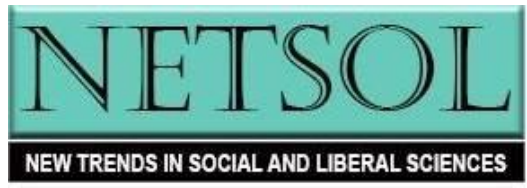


2008. Reinventing the Sacred: A New View of Science, Reason, and Religion. New York: Basic Books. 2016. Humanity in a Creative Universe. New York: Oxford University Press. . 2019. The World Beyond Physics: The Emergence and Evolution of Life. New York: Oxford University Press.

Kavalski, Emilian, ed. 2015. World Politics at the Edge of Chaos: Reflections on Complexity and Global Life. Albany: State University of New York Press.

Keohane, Robert A. and Joseph S. Nye. 2011. Power and Interdependence. $4^{\text {th }}$ ed. Boston: Longman.

Klimek, Peter, Ricardo Hausmann, Stefan Thurner. 2012. "Empirical confirmation of creative destruction from world trade data." Harvard University Center for International Development Working Paper No. 238 (April) at https://dash.harvard.edu/bitstream/handle/1/8832941/RWP12022_Hausmann.pdf?sequence=1\&isAllowed=y (accessed 4/24/2018).

Levitsky, Steven and Daniel Ziblatt. 2018. How Democracies Die. New York: Crown.

Marx, Karl. 1848. Manifest der Kommunistichen Partei; Communist Manifesto. Many editions.

Lorenz, E. N. 1963. “Deterministic Nonperiodic Flow.” Journal of Atmospheric Science 20:13140.

. 1965. "A Study of the Predictability of a 28-Variable Atmospheric Model." Tellus $17: 321-333$ https://www.researchgate.net/publication/227661690_A_Study_of_the_Predictability_of _a_28-Variable_Atmospheric_Model (accessed 4/22/2018).

McCraw, Thomas. 2007. Prophet of Innovation: Joseph Schumpeter and Creative Destruction. Boston: Harvard Business School Press.

Morris, Ian. 2010. Why the West Rules-For Now: The Patterns of History, and What They Reveal About the Future. New York: Farrar, Straus and Giroux.

Nicholas, Tom. 2003. "Why Schumpeter Was Right: Innovation, Market Power, and Creative Destruction in 1920s America." Journal of Economic History 63, 4 (December) at https://www.hbs.edu/faculty/Pages/item.aspx?num=24067 (accessed 4/28/2018).

Ouellette, Jennifer. 2014. "A Fundamental Theory to Model the Mind." Quanta (April 7) at https://www.quantamagazine.org/toward-a-theory-of-self-organized-criticality-in-thebrain-20140403/ (accessed 3/5/2018).

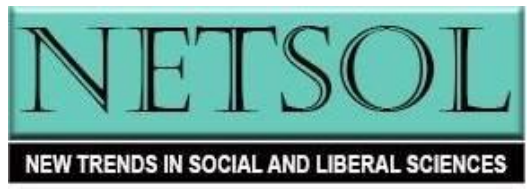


Pezard, L. and J.L. Nandrino. 2001. "Dynamic paradigm in psychopathology: 'chaos theory', from physics to psychiatry." Encephale 27, 3 (May-June):260-268.

Perry, Mark J. 2014. "America's Biggest Companies, Then and Now (1955 to 2010)." AEIdeas (August 18)@ @https://247wallst.com/investing/2010/09/21/americas-biggest-companiesthen-and-now-1955-to-2010/ (accessed 4/25/2018).

Pruessner, Gunnar. 2012. Self-Organized Criticality: Theory, Models and Characterisation. Cambridge, UK: Cambridge University Press.

Rose, Gideon. 2019. "The Fourth Founding: The United States and the Liberal Order." Foreign Affairs 98, 1 (January-February) at https://www.foreignaffairs.com/articles/unitedstates/2018-12-11/fourth-founding (accessed 1/10/2019).

Rostow, Walt W. 1960. The Stages of Economic Growth: A Non-Communist Manifesto. Cambridge, UK: Cambridge University Press.

Schumpeter, Joseph A. 1936. The Theory of Economic Development: An Inquiry into Profits, Capital, Interest, and the Business Cycle. Cambridge: Harvard University Press [first published 1911]. 1942. Capitalism, Socialism, and Democracy. New York: Harper \& Brothers. 1964. Business Cycles: A Theoretical, Historical, and Statistical Analysis. New York: McGraw-Hill. [first published 1939].

Snyder, Timothy. 2018. The Road to Unfreedom: Russia, Europe, America. New York: Tim Duggan Books.

Toynbee, Arnold J. 1947, 1957. A Study of Civilization. 2 vols. New York: Oxford University Press.

United Nations Development Program (annual), Human Development Index at http://hdr.undp.org/en/content/human-development-index-hdi (accessed 12/8/2018).

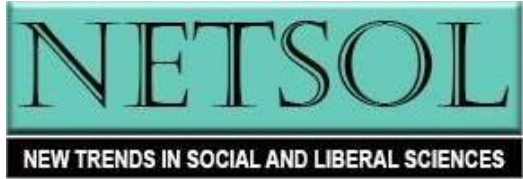

